\title{
Experimental study of auxetic behavior of re-entrant honeycomb with curvilinear elements
}

\author{
R. V. Goldstein, D. S. Lisovenko ${ }^{\dagger}$, A. V. Chentsov, S. Yu. Lavrentyev \\ †lisovenk@ipmnet.ru
}

Institute for Problems in Mechanics, RAS, prospect Vernadskogo 101, b1, Moscow, 119526, Russia

The mechanical behavior of a two-dimensional structure with negative Poisson `s ratio (auxetic structure) was experimentally studied. The concave hexagon (re-entrant honeycomb) with straight sides is often an element of auxetic structures. In this paper, a new design of a concave hexagon in which a part of straight elements is replaced with curvilinear elements is suggested. The sample $(110 \times 20 \times 0.7 \mathrm{~mm}$ plate with the central part of $26.2 \times 20 \times 0.7 \mathrm{~mm})$ was made by the laser cutting method from nonauxetic polyethyleneterephthalate (PET-a amorphous) plates. The transverse size of elements of hexagons is equal to sample thickness. The sample was subjected to a monotonous uniaxial tension until the last moment when it still maintained its planarity. As a result of experimental data processing the tensile force - displacement diagram was calculated. Variability of Poisson`s ratio depending on engineering deformations was studied. The analysis showed that auxetic structure at tension attained the maximum longitudinal deformation (before loss of stability) of 99\%, and the maximum transverse deformation of $59 \%$. Elastic deformations reached $2 \%$. Poisson`s ratio defined by analogy with elastic small deformations varies in the range from -0.19 to -0.60 with an increase of longitudinal and transverse deformations.

Keywords: auxetic, Poisson`s ratio, polymer, metamaterial, re-entrant honeycomb.

\section{Экспериментальное изучение ауксетического поведения вогнутой ячеистой решетки с криволинейными элементами}

\author{
Гольдштейн Р. В., Лисовенко Д. С. ${ }^{\dagger}$, Ченцов А. В., Лаврентьев С. Ю. \\ †lisovenk@ipmnet.ru
}

Институт проблем механики им. А.Ю. Ишлинского РАН. 119526, Москва, просп. Вернадского, д.101, корп.1

Экспериментально исследовано механическое поведение двумерной конструкции с отрицательным коэффициентом Пуассона (ауксетической конструкции). В ауксетических конструкциях часто элементом является вогнутый шестиугольник с прямыми сторонами. В данной работе предложен новый дизайн вогнутого шестиугольника, в котором часть прямых элементов заменена на криволинейные элементы. Образец, размерами $110 \times 20 \times 0.7$ мм с центральной зоной $26.2 \times 20 \times 0.7$ мм, был изготовлен из неауксетического полиэтилентерефталата (ПЭТ-а аморфный), методом лазерной резки. Поперечный размер элементов шестиугольников равен толщине образца. Образец был подвергнут монотонному одноосному растяжению до момента, когда он еще оставался плоским. В результате обработки экспериментальных данных построена диаграмма растягивающая сила - перемещение, а также исследована изменчивость коэффициента Пуассона в зависимости от инженерных деформаций. Анализ показал, что в результате растяжения ауксетической конструкции максимальная продольная деформация составила (до потери устойчивости) 99\%, а максимальные поперечные деформации - 59\%. Упругие деформации достигают 2\%. Коэффициент Пуассона, определенный по аналогии с упругими малыми деформациями, меняется в интервале от -0.19 до -0.60 при увеличении продольных и поперечных деформаций.

Ключевые слова: ауксетики, коэффициент Пуассона, метаматериал. 


\section{Introduction}

A material with negative Poisson's ratio (auxetic) polymeric foam [1] was obtained for the first time in 1987. From this time active theoretical and experimental studies of physical and mechanical properties of materials and structures with negative Poisson's ratio have started. In a study of auxetics it is possible to allocate the following main directions - creation of auxetic rod models and structures [2-7], production of composites [6,8-11] and polymer foams $[1,12,13]$ with effective negative Poisson's ratio, a study of auxetic crystal materials [6,14-20]. For example, auxetic rod models and structures can be used as elements of a new class of composites. Negative Poisson's ratio can also be detected due to anisotropy of the elastic media [14-22], re-entrant honeycombs $[12,13]$, rotating rigid units [23,24], polydispersity [25], fractal structure [26], applied negative hydrostatic pressure $[27,28]$, and excitation of nonlinear vibrational modes [29].

For the first time plane auxetic structures were considered in [2-4]. In [2] the two-dimensional structure consisting of concave hexagons was suggested and values of geometrical parameters at which Poisson's ratio equals -1 were given. In [3] the auxetic framework which is also fabricated of concave hexagons was considered and calculations of average elastic characteristics were given. In [4] auxetic properties were revealed in the two-dimensional plane consisting of convex hexagons. Experimental study of the two-dimensional and three-dimensional auxetic polymeric constructions was carried out in [5]. In this paper dependences of Poisson's ratio on true deformation were obtained.

The concave hexagon (re-entrant honeycomb) with "straight" elements is often used as a unit cell in a study of mechanical properties of cellular structures (see the book [6] and the review [7]). The design of the auxetic two-dimensional plane consisting of concave hexagons is suggested below in the present work. Variability of Poisson's ratio is also investigated. Some sides of the generating hexagon of this plane have the curvilinear form (Fig. 1).

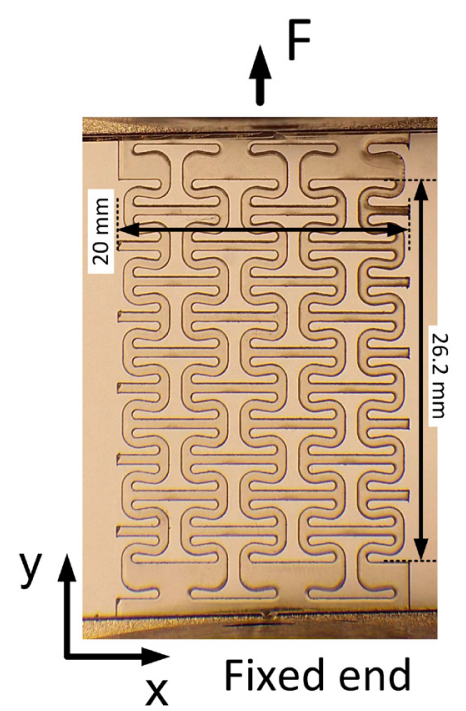

Fig. 1. (Color online) Design of the central part $(26.2 \times 20 \mathrm{~mm})$ of the two-dimensional auxetic plane. Axis y corresponds to tension direction, and axis $\mathrm{x}$ corresponds to the transverse direction.

\section{Methods}

Samples were made of $0.7 \mathrm{~mm}$ thick polyethyleneterephthalate (PET-a amorphous) plates by the femtosecond laser cutting method. Processing quality of this method exceeds any other existing laser systems (for example, widespread $\mathrm{CO}_{2}$ lasers). Femtosecond laser processing yields almost no side effects related to material heating. Duration of a femtosecond laser impulse is so short that its thermal influence after its interaction with material does not extend to adjacent sites. Material is exposed to ablation. The main advantage of this method is high precision and selectivity, as transition to plasma happens only in the focus of a laser beam (spot size is from tens of microns to several hundred nanometers). Thus, mechanical properties of the material in the areas adjoining the place of processing do not change. Samples were made on a laser machine with a femtosecond laser. The laser machine provided displacements of billet with micron accuracy. The average power of radiation was $3 \mathrm{~W}$. Duration of the laser pulses was $500 \mathrm{fs}$. Energy of laser pulse was $120 \mu \mathrm{J}$. Thus, radiation power in laser pulse reached $240 \mathrm{MW}$. A $110 \times 20 \times 0.7 \mathrm{~mm}$ sized plate with the central part of $26.2 \times 20 \times 0.7 \mathrm{~mm}$ (Fig. 1) was cut out. The design of the sample were such that the transverse size of elements of concave structure was chosen equal to the plate thickness.

The sample was subjected to a monotonous uniaxial tension by force $\mathbf{F}$ on a universal uniaxial setup MTS Synergie 400 up to a load of $50 \mathrm{~N}$ with a speed of $5 \mathrm{~mm} / \mathrm{min}$. Changes of sample geometry was registered in 12-Megapixel images obtained during the experiment. Force and displacements of cantilever-moving beam of upper grip were also registered by the built-in sensors of the setup.

\section{Results and discussion}

In Fig. 2a a tensile force - displacement diagram is given $\left(\mathrm{F}-\Delta \mathrm{l}_{\mathrm{y}}\right)$. As one can see from the figure, the dependence is almost linear up to $5 \mathrm{~mm}$ displacement, and from $5 \mathrm{~mm}$ to $10 \mathrm{~mm}$ the sample is elongated with no force increase. There is a nonlinear load increase at further tension. During the experiment, the maximum displacement was $25.9 \mathrm{~mm}$. Up to this value the sample remained plane. The transverse displacement $\Delta \mathrm{l}_{\mathrm{x}}$ versus longitudinal displacement $\Delta \mathrm{l}_{\mathrm{y}}$ is given in Fig. 2b. The maximum transverse displacement is equal to $11.9 \mathrm{~mm}$. It should be noted that longitudinal displacement during the experiment appears several times higher than the transverse displacement.

Poisson's ratio in the elasticity theory of small deformations is determined by the formula

$$
v=-\varepsilon_{\mathrm{x}} / \varepsilon_{\mathrm{y}},
$$

where $\varepsilon_{\mathrm{y}}-$ longitudinal deformation, $\varepsilon_{\mathrm{x}}-$ transverse deformation. Variability of Poisson's ratio was studied by analogy with this formula. In the case under consideration $\varepsilon_{\mathrm{y}}=\Delta \mathrm{l}_{\mathrm{y}} / \mathrm{L}_{0}$ is longitudinal deformation, $\mathrm{L}_{0}=26.2 \mathrm{~mm}$ the length of the central area, $\varepsilon_{x}=\Delta \mathrm{l}_{\mathrm{x}} / \mathrm{l}_{0}$ is transverse deformation, and $l_{0}=20 \mathrm{~mm}$ is the width of the central area. Photographs of the sample at different stages of deformation are presented in Fig. 3. The analysis of experimental data showed that elastic 
deformation for this sample occurs up to $2 \%$ longitudinal deformation. The remaining part of deformation accounts for plastic deformation.

Poisson's ratio dependence on longitudinal and transverse deformations is given in Fig. 4. As a result of tension of the two-dimensional plane, the maximum longitudinal deformations reached $99 \%$, and the maximum transverse deformation is 59\%. As seen from Fig. 4, Poisson`s ratio remains constant up to $11 \%$ longitudinal deformation and is close to -0.2 . Poisson's ratio decreases to -0.6 with a further increase of longitudinal deformation.

\section{Conclusion}

A new design of an auxetictwo-dimensional structure has been suggested. The concave hexagon was chosen as a generating element of this structure. Unlike a common hexagon with straight sides, in this paper a part of straight sides is replaced with curvilinear ones. The sample with such an auxetic design made of nonauxetic polyethyleneterephthalate (PET-a amorphous) by femtosecond-laser cutting was subjected to a monotonous uniaxial tension. The analysis of experimental data showed that Poisson's ratio of such auxetic structure is changed in the range from -0.19 to -0.6 .

The considered auxetic structure can be used in composite materials for a production of materials with predetermined mechanical properties.

Acknowledgements. Authors are grateful to V. A. Gorodtsov and N. G. Solovyov for useful discussion of the results. The work was accomplished within the framework of the Project of RFBR and Moscow Government N 15-31-70005 mol_a_mos.
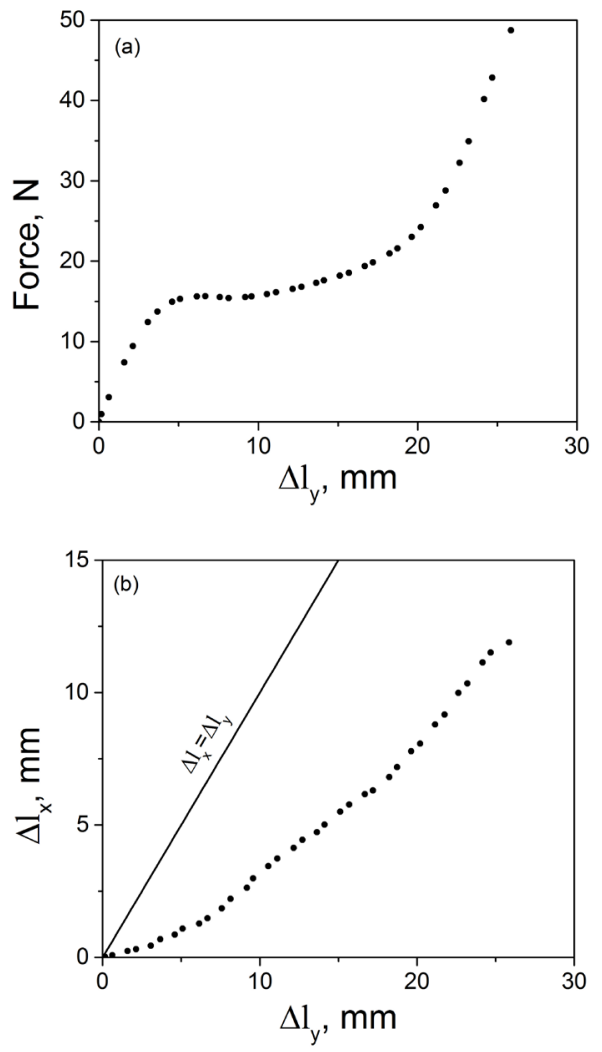

Fig. 2. Tensile force - displacement $\left(\mathrm{F}-\Delta \mathrm{l}_{\mathrm{v}}\right)$ diagram (a) and transverse displacement $\Delta \mathrm{l}_{\mathrm{x}}$ versus longitudinal displacement $\Delta \mathrm{l}_{\mathrm{y}}$ (b).
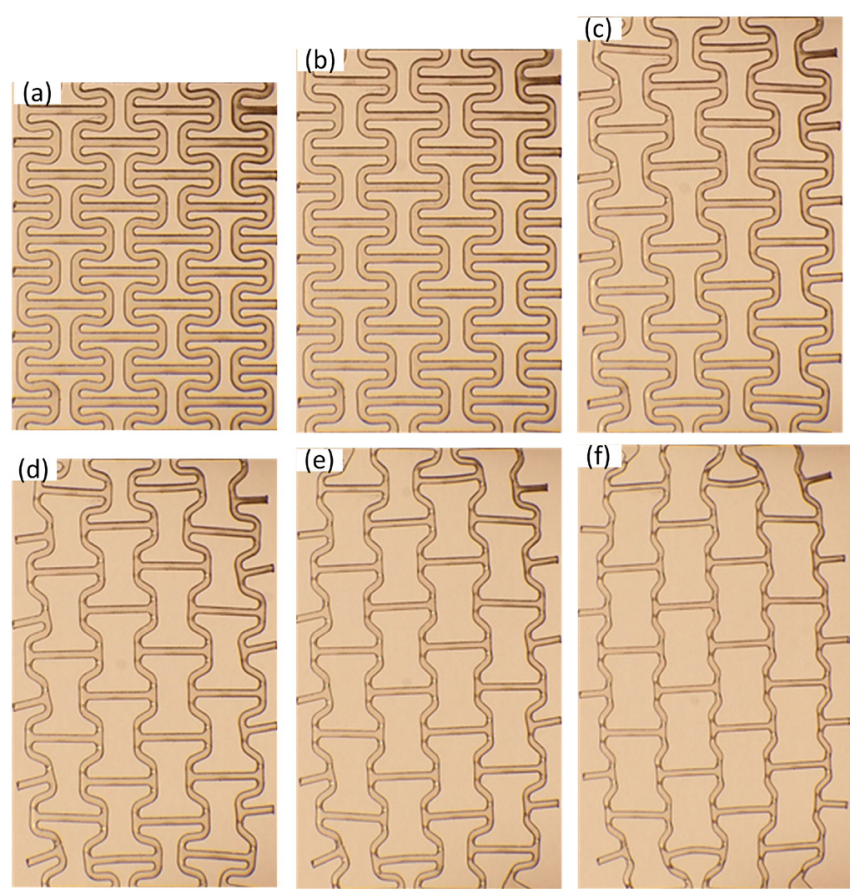

Fig. 3. (Color online)

Photographs of the sample at different stages of deformation: $\varepsilon_{\mathrm{x}}=0, \quad \varepsilon_{\mathrm{y}}=0$ (a); $\varepsilon_{\mathrm{x}}=0.034, \varepsilon_{\mathrm{y}}=0.140$ (b); $\varepsilon_{\mathrm{x}}^{\mathrm{x}}=0.110,{ }^{\mathrm{y}} \varepsilon_{\mathrm{y}}=0.311$ (c); $\varepsilon_{\mathrm{x}}=0.222,{ }^{\mathrm{y}} \varepsilon_{\mathrm{y}}=0.486$ (d); $\varepsilon_{\mathrm{x}}^{\mathrm{x}}=0.315, \varepsilon_{\mathrm{y}}^{\mathrm{y}}=0.658(\mathrm{e}) ; \varepsilon_{\mathrm{x}}^{\mathrm{x}}=0.499, \varepsilon_{\mathrm{y}}^{\mathrm{y}}=0.866$ (f). Axis $\mathbf{y}$ corresponds to tension direction, and axis $\mathbf{x}$ corresponds to the transverse direction.
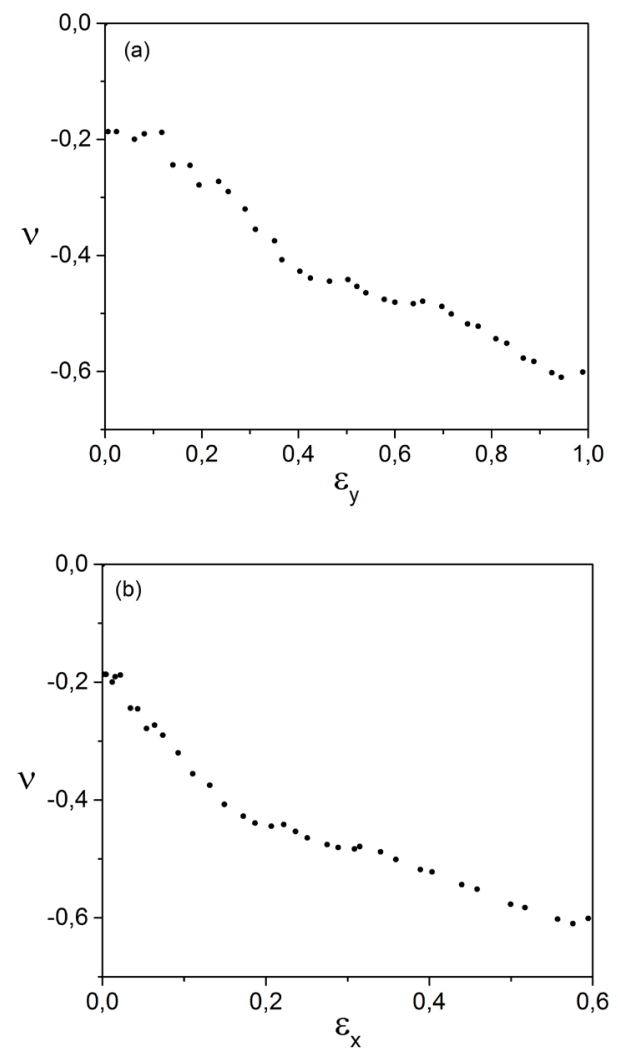

Fig. 4. Poisson`s ratio as a function of longitudinal deformation $\varepsilon_{\mathrm{y}}$ (a) and transverse deformation $\varepsilon_{\mathrm{x}}(\mathrm{b})$. 


\section{References}

1. R. Lakes. Science 235 (4792), 1038 (1987). DOI: $10.1126 /$ science. 235.4792 .1038

2. R.F. Almgren. J. Elasticity 15 (4), 427 (1985). DOI: 10.1007/BF00042531

3. A. G. Kolpakov, Prikl. Mat. Mekh. 59, 969 (1985).

4. D. Y. Fozdar, P. Soman, J. W. Lee, L.-H. Han, S. Chen, Adv. Func. Mater. 21 (14), 2712 (2011). DOI: $10.1002 /$ adfm. 201002022

5. L. J. Gibson, M.F. Ashby, G.S. Schajer, C.I. Robertson. Proc. Royal Soc. London A 382, 25 (1982). DOI: 10.1098/rspa.1982.0087

6. T.-C. Lim, Auxetic Materials and Structures. Springer Singapore.(2015) 588 p. DOI: 10.1007/978-981-287-275-3

7. H.M. A. Kolken, A. A. Zadpoor, RSC Adv. 7 (9), 5111 (2017). DOI: 10.1039/C6RA27333E

8. M. Bilski, K. W. Wojciechowski. Phys. Status Solidi B 253 (7), 1318 (2016). DOI: 10.1002/pssb.201600140

9. L. Zhou, L. Jiang, H. Phys. Status Solidi B 253 (7), 1331 (2016). DOI: 10.1002/pssb.201552768

10. H. Jopek. Phys. Status Solidi B 253 (7), 1369 (2016) DOI: 10.1002/pssb.201600117

11. R.V. Goldstein, V.A. Gorodtsov, D.S. Lisovenko. Eur. J. Mech. A Solids 63, 122 (2017). DOI: 10.1016/j. euromechsol.2017.01.001

12. A. Alderson, Chem. Ind. 17, 384 (1999).

13. K.E. Evans, A. Alderson, Adv. Mater. 12 (9), 617 (2000). DOI: $10.1002 /(\mathrm{SICI}) \quad 1521-4095 \quad$ (200005) 12:9<617::AID-ADMA617>3.0. CO;2-3

14. K. L. Alderson, V.R. Simkins, V.L. Coenen, P. J. Davies, A. Alderson, K.E. Evans, Phys. Status Solidi B, 242 (3), 509 (2005). DOI: 10.1002/pssb.200460371

15. A.C. Branka, D.M. Heyes, Sz.Mackowiak, S. Pieprzyk, K. W. Wojciechowski, Phys. Status Solidi B 249 (7), 1373 (2012). DOI: 10.1002/pssb.201084222
16. R.V. Goldstein, V.A. Gorodtsov, D.S. Lisovenko. Mech. Solids, 45 (4), 529 (2010). DOI: 10.3103/S0025654410040047

17. R. V. Goldstein, V.A. Gorodtsov, D.S. Lisovenko. Phys. Status Solidi B, 250 (10), 2038 (2013). DOI: $10.1002 /$ pssb.201384233

18. R. V. Goldstein, V.A. Gorodtsov, D. S. Lisovenko. Letters on Materials, 3 (1), 7 (2013). DOI: 10.22226/2410-35352013-1-7-11

19. R.H. Baughman, J.M. Shacklette, A.A. Zakhidov, S. Stafström, Nature 392 (6674), 362 (1998). DOI: $10.1038 / 32842$

20. V. V. Krasavin, A. V. Krasavin, Phys. Status Solidi B 251 (11), 2314 (2014). DOI: 10.1002/pssb.201451129

21. R.V. Goldstein, V.A. Gorodtsov, D.S. Lisovenko. Dokl. Phys., 58 (9), $400 \quad$ (2013). DOI: 10.1134/S1028335813090097

22. R.V. Goldstein, V.A. Gorodtsov, D.S. Lisovenko, M.A. Volkov. Dokl. Phys. 61 (12), 604 (2016). DOI: 10.1134/S1028335816120016

23. D. Attard, J. N. Grima. Phys. Status Solidi B 245 (11), 2395 (2008). DOI: 10.1002/pssb.200880269

24. J. N. Grima, P.-S. Farrugia, R. Gatt, D. Attard. Phys. Status SolidiB, 245(3), 521 (2008).DOI: 10.1002/pssb.200777705

25. J.W. Narojczyk, K.W. Wojciechowski. J. Non-Cryst. Solids 356 (37-40), 2026 (2010). DOI: 10.1016/j. jnoncrysol.2010.05.080

26. V. V. Novikov, K. W. Wojciechowski. Phys. Solid State 41 (12), 1970 (1999). DOI: 10.1134/1.1131137

27. K. W. Wojciechowski, Mol. Phys. Rep. 10, 129 (1995).

28. R. V. Goldstein, V.A. Gorodtsov, D.S. Lisovenko. Phys. Status Solidi B 253 (7), 1261 (2016). DOI: 10.1002/pssb.201600054

29. S. V. Dmitriev, E. A. Korznikova, D. I. Bokij, K. Zhou. Phys. Status Solidi B 253 (7), 1310 (2016). DOI: 10.1002/pssb.201600086 